\title{
Özerklik, Büyüme ve Kalite: İlhan Tekeli'nin Yükseköğretim Çalışmaları Üzerine Bir Değerlendirme
}

\author{
* \\ Zafer Çelik ${ }^{1}$ \\ ORCID: 0000-0003-0080-1142
}

\section{Öz}

İlhan Tekeli, yaklaşık 50 yıllık süreçte yükseköğretim meselelerine yönelik birçok makale ve kitap yazmış, konuşmalar yapmıştır. Bu çalışma, İlhan Tekeli'nin Türkiye yükseköğretim tarihi, sorunları ve yükseköğretimdeki dönüşümler ile yükseköğretimde özerklik, büyüme ve kalite konularmı nasıl tartıştı̆̆ına odaklanmıştır. Tekeli'ye göre ideal üniversite, rektörünün öğretim üyeleri tarafindan seçildiği Humboldt tarzı üniversitedir. Ona göre İkinci Dünya Savaşından sonra üniversite dönüşmeye başlamış ve özerkliğini kaybetmiştir. Türkiye'de ise üniversitelerin 1946 yılında elde ettiği 1961 Anayasası ile kurumsallaştırdığı özerklik, YÖK'ün kurulmasıyla sona ermiştir. YÖK oldukça geniş yetkilere ve aşırı merkeziyetçi bir yapıya sahip olarak üniversiteler üzerinde denetimi iyice artmıştır. Ayrıca, Tekeli idari özerkliği üniversiteye içkin temel özellik olarak tanımlamıştır. Tekeli'ye göre aşırı güçlü ve yetkili rektörlerin varlı̆̆ı öğretim üyelerinin akademik özgürlü̆̆̈̈ ve katılımcı yönetim için en önemli sorunlardan biridir. Tekeli, üniversite özerkliğini sağlayacak, üniversiteleri daha demokratik kılacak bir reform ihtiyaç olduğunu belirtmiştir. Ayrıca Tekeli, yükseköğretim sisteminin büyümeye gereksinimi olduğunu ancak sistemin büyümesi için nitelikli doktoral öğretim elemanlarının yetiştirilmesine öncelik verilmesi gerektiğini vurgulamıştır.

Anahtar Kelimeler: İhan Tekeli, yükseköğretim, özerklik, büyüme, kalite

${ }^{1}$ Doç. Dr., Ankara Yıldırım Beyazıt Üniversitesi, E-mail: zcelik@ybu.edu.tr

idealkent @ Kent Araştırmaları Dergisi (Journal of Urban Studies)

http://idealkentdergisi.com

Geliş Tarihi Received Date: 01.04.2020 Kabul Tarihi Accepted Date: 25.04.2020 


\title{
Autonomy, Expansion, and Quality in Higher Education: An Analysis on İlhan Tekeli's Research on Higher Education
}

\author{
Zafer Çelik ${ }^{2}$ \\ ORCID: 0000-0003-0080-1142
}

\begin{abstract}
For about 50 years Ilhan Tekeli has been a paramount figure who has written many articles and books on higher education issues in Turkey. This study focuses on how Tekeli discusses Turkey's higher education history, problems and autonomy in higher education, evolution of higher education, growth and quality issues. Tekeli claims, in 1946 universities became autonomous and the autonomy constitutionalized with the 1961 Constitution, which gave universities a broader autonomy. But after the establishment of the Board of Higher Education (BHE) in 1981, universities lost their autonomy, and were put under the control of central administration with the increased pressure over the universities. Tekeli defined administrative autonomy as a key feature of the university. For Tekeli, extremely strong and exceptional powers of rectors bring about hardly impossible to mention the freedom of faculty members and a participatory administration.Tekeli stated that there is a need for a reform that will provide autonomy and make universities more democratic. Also, Tekeli emphasized that expansion of the higher education system cannot be assured by without giving priority to the training of qualified doctorate academics.
\end{abstract}

Keywords: IIhan Tekeli, higher education, autonomy, expansion, quality

2 Assoc. Prof. Dr., Ankara Yıldırım Beyazıt University, E-mail: zcelik@ybu.edu.tr

idealkent @ Kent Araştırmaları Dergisi (Journal of Urban Studies)

http://idealkentdergisi.com

Geliş Tarihi Received Date: 01.04.2020 Kabul Tarihi Accepted Date: 25.04.2020 


\section{Giriş}

İlhan Tekeli 1970'li yıllardan günümüze yaklaşık 50 yıllık süreçte oldukça üretken bir araştırmacı ve yazar olarak planlama, kentleşme, tarih, eğitim gibi sosyal bilimlerin pek çok alanında çalışmalar yapmıştır. Bu çalışmaları arasında yükseköğretim meselelerini ele aldığı eserleri, Türkiye yükseköğretim tarihinin seyrini anlamak için oldukça değerlidir. Türkiye'de yükseköğretim üzerine yapılan araştırmaların son yıllarda artmasına rağmen oldukça sınırlı olduğu dikkate alındığında Tekeli'nin hem akademisyen hem YÖK üyesi hem de araştırmacı olarak eserleri Türkiye yükseköğretim alanı için oldukça önemlidir.

Tekeli gibi, hem uzun yıllar yükseköğretim kurumlarında akademisyen olarak çalışan hem de rektörlük, YÖK üyeliği ve YÖK başkanlığı yaparak yükseköğretim politikalarının belirlenmesinde oldukça önemli isimlerin yazdıkları eserler Türkiye'de yükseköğretimin gelişimini anlamak açısından oldukça kritik bir öneme sahiptir. Örneğin, Doğramac (2007), Türkiye ve dünyada yükseköğretimde yaşanan gelişmeleri bazı temel alanlarda incelediği küçük bir eser ile kritik aktörlerin yükseköğretimi nasıl değerlendirdiğini göstermiştir. Buna ilaveten, Gürüz (2008), Türkiye eğitim sistemini genel olarak tarihsel ve karşılaştırmalı olarak ele almış ve yükseköğretime ilişkin finansman, yönetim, yükseköğretime geçiş gibi hususları tartışmıştır. Buna ilaveten Gürüz (2015)'ün, rektörlük ve YÖK başkanlığı yaptı̆̆ dönemlerdeki anılarını anlatmıştır. Gürüz'ün bu çalışmaları, Türkiye yükseköğretim tarihinin en gergin yıllarını anlamak açısından oldukça önemlidir. Benzer bir şekilde Boğaziçi Üniversitesi rektörlüğü yapan ve yükseköğretim alanında birçok rapor, kitap ve değerlendirme yazıları gibi çalışmaların önemli isimlerinden olan Ergüder (2015)'in anıları da Türkiye yükseköğretim sisteminin işleyişini anlamak açısından değerlidir. Buna ilaveten uzun yıllar YÖK üyesi olarak görev yapmış olan ve yükseköğretimin farklı meseleleri üzerine çalışmalar yapmış olan Durmuş Günay (2019a, 2019b)'ın çalışmaları Türkiye'de üniversite meselesini anlama açısından önemli hususları içermektedir.

Tekeli'nin yükseköğretim politikalarına yön veren bu isimlerden belki de en önemli farkı, çok daha erken bir tarihte, YÖK üyesi olarak yükseköğretim politikalarını belirleme konusunda kritik bir aktör olmadığı dönemlerden çok daha öncesinde yükseköğretim meseleleri üzerine düşünmesi ve bu konuda çalışmalar yapmasıdır. Buna ilaveten, İlhan Tekeli yükseköğretime yönelik çok farklı alanlarda çalışmalar yapmıştır. Tekeli'nin Osmanlı eğitim ve 
bilim tarihi, Türkiye yükseköğretiminin tarihsel gelişimi, yükseköğretim sistemini iyileştirmek için öneriler ve özerklik konuları gibi çeşitli alanlarda araştırmaları vardır. Yükseköğretim meselelerini ve tarihini çok farklı boyutlardan uzun yıllar boyunca inceleyen Tekeli'nin yükseköğretim tarihi ve meselelerine ilişkin kritik hususları nasıl ele aldığını analiz etmek, Türkiye yükseköğretim sisteminin gelişimini ve yarınını anlamak için öğretici olacaktır. Bundan dolayı bu çalışmada Tekeli'nin üniversite meselesine nasıl yaklaştığ ve yükseköğretim sistemini iyileştirmek için neler yapılması gerektiği, Türkiye yükseköğretim tarihini nasıl değerlendirdiği, özerklik meselesini nasıl ele aldığı ve yükseköğretimde büyüme ve kalite ilişkisine nasıl yaklaştı̆̆ incelenecektir. Çalışmada Tekeli'nin düşüncelerinden yola çıarak Türkiye yükseköğretim sisteminde çok tartışlan özerklik, büyüme ve kalite gibi hususlara dair değerlendirmelerde bulunulacaktır.

\section{Tekeli'nin ideal üniversitesi: Humboldt tarzı üniversite ve özerklik}

Tekeli, ideal üniversite olarak 1810 y1lında kurulan Berlin Üniversitesi'ni (Berlin Humboldt Üniversitesi) tanımlamaktadır. Tekeli, tarihsel olarak üniversitenin üç aşamadan geçtiğini belirtir: 1. Ortaçağın kilise merkezli üniversitesi 2. Ulus devletler dünyasının üniversitesi (Von Humboldt Üniversitesi) 3. Bilgi toplumu Üniversitesi (Multiversite) (Tekeli, 2010b).

Tekeli, kilise merkezli üniversitede temel esasın öğretim olduğunu, öğrenci ya da öğretim üyeleri toplulukları tarzında özerk loncalar altında örgütlendiğini, meslektaşlar arası yönetim anlayışının hâkim olduğunu, finansın öğrenciler tarafından karşılandığı belirtmektedir (Tekeli, 2010b). Humboldt tarzı üniversitede ise kilise merkezli üniversiteden farklı olarak öğretime ilaveten araştırma da gerçekleştirilmektedir. Başka bir ifade ile sadece var olan bilginin tekrarı ve öğretimi değil, aynı zamanda yeni bilgi üretimi de esastır. Tekeli, bilimin üniversiteye dönüşü ve doğrudan araştırmaların yapılmasının Berlin Humboldt Üniversitesinin kuruluşu ile gerçekleştiğini belirtmektedir. Bilgi üretimi kürsüler, enstitüler vb. olarak örgütlenen akademisyenler topluluğunca gerçekleştirilmektedir. Humboldt üniversitesi ile birlikte bilim tek insanın gayreti yerine üniversite öğretim üyeleri ve öğrencilerinin ortaklaşa çabaları ile üretilmeye başlanmıştır. Bu üniversite modelinde bilim için bilim esastır, doğrudan mesleğe yönelik pratik eğitimler teknik yüksekokullarda gerçekleştirilmektedir. Tekeli, Humboldt tarzı üniversitede, özerkliğin oldukça geniş olduğunu, meslektaşlar arası yönetim modelinin benimsen- 
diği, eşitler arası birinci anlayışı temelinde rektörün kısa süreli olarak seçildiğini belirtmektedir. Tekeli'nin ifadesine göre Humboldt tarzı üniversite kendi öğretim programın belirlemekte, devlet üniversiteyi yönetme konusunda müdahale etmemekte, sadece harcama denetimini yapmaktadır (Tekeli, 1989; Tekeli, 2010b).

Tekeli, ideal üniversite modeli olarak tanımladığı Humboldt tarzı üniversitenin İkinci Dünya Savaşı sonrasında dönüşmeye başladığını ve üniversiteye içkin birçok temel ilkenin yok olduğunu iddia etmektedir. Bu dönüşen üniversiteye Tekeli, Clark Kerr'e atıf ile multiversite adını vermektedir. Multiversitede öğretim ve araştırmaya ilaveten topluma hizmet ilkesi ortaya çımıştır. Meslektaş yönetimi anlayışının hâkim olduğu, öğretim üyelerinin seçimi ile rektörün eşitler arası birinci olduğu yaklaşımdan profesyonel, atama ile gelen ve uzun süreliğine atanan rektör uygulamasına geçilmiştir. Üniversite artık sadece bir akademisyenler topluluğu değildir. Tekeli'ye göre multiversite piyasaya çok duyarlı hale gelmiş, bilim için bilim anlayışı terk edilmiş, pratik araştırmalar ve teknik okullar üniversite içinde yer almaya başlamıştır. Öğretim üyeleri, bilimsel katkılarından ziyade üniversiteye getirdiği proje ve fonlar ile değerlendirilmeye başlanmış, dersler tüketici eğilimlere göre düzenlenmiştir. Bilginin metalaşması, üretim sisteminde yaşanan değişim, beşerî sermayenin öneminin artması ile üniversite mezununa talep artmış ve üniversite elit bir sistem olmaktan çıarak herkese açık hale gelmiştir. Üniversitenin finansmanında öğrenci, piyasa ve devlet hepsi rol almaya başlamıştır. Buna ilaveten, dış değerlendirme süreçleri artmıştır. Üniversitenin piyasa ilişkilerine indirgenmesi üniversite içi dayanışmayı azaltmış ve dolayısıyla üniversitenin kimliği zayıflamıştır (Tekeli, 2010b; t.y.). Üniversitenin piyasaya duyarlı hale gelmesi ile bilgi metalaşmış, araçsal bir boyuta indirgenmiş, kamu malı olma yerine mülkiyet ve gizliliğin konusu haline gelmiş ve özelleşmiştir. Bilginin kamusal faydası ve toplumsal refaha katkısı yerine firmalara katkısı öne çıkmış ve bilim insanın bilgiye atfettiği toplumsal yarar anlayışı kaybolmuştur. Öğretim üyeleri bilgiye bir aydın ya da düşünür olarak değil, daha profesyonel bir şekilde yaklaşan akademisyenlere dönüşmüştür (Tekeli, 1989).

Tekeli'ye göre üniversite toplum ve siyasetten uzak bir ortamda gelişmiş ve bu ona üniversitenin en önemli özelliği olan özerkliği sağlamıştır. Üniversite yıllar içerisinde farklı tarihsel ve toplumsal ortamlarda değişik tanımlara sahip olsa da diğer kurumlarla kıyaslandığında çok daha özerk bir kurumdur. Bu özellikler üniversiteye mikrokozmoz olma özelliği vermektedir. 
Özerkliği sağlayan en temel husus ise meslektaş yönetimi anlayışı içinde rektörün öğretim üyeleri tarafından seçilmesidir. Buna ilaveten Tekeli, bilimsel özerkliği sağlayan aktörlerin meslektaşlar birliği olduğunu ifade eder. Çünkü meslektaşlar, kendi programlarını ve kurallarını belirler. Tekeli'ye göre meslektaşlar birliği, bilimsel üretimi kolaylaştıran ve mükemmelleştiren demokratik bir ortam için gereklidir. Meslektaş ortamında bireylerin görüş ve düşüncelerini, kaygilarını rahat bir şekilde ifade etmeleri, yeni düşüncelerin doğması ve gelişmesine katkı sunması için gereklidir. (Tekeli, 1989, 2010a, 2011). Tekeli'ye göre günümüzde piyasa değerlerinin egemen olmasının sonucu olarak, üniversitenin toplum ve siyaset ile olan sınırları ortadan kalkmış ve bin yıllık mirası olan özerklik ve mikrokozmoz olma hali tehdit altına girmiştir. Çünkü rektörler meslektaş yönetimi anlayışı içinde öğretim üyeleri tarafından değil, profesyonel bir yönetici olarak atama ile gelmeye başlamıştır. Üniversitede meslektaş ortamı kaybolmuş, performansa dayalı bir ortam gelişmiştir. Buna ilaveten, üniversitenin piyasa duyarlı hale gelmesi, firmalar tarafından denetlenme, üniversite dışı için araştırmaların yapılması özerkliği olumsuz etkilemiştir (Tekeli, 1989, 2011).

Tekeli, üniversitenin toplumdan uzak olmasını, meseleleri kendi iç etiği içinde pragmatik bir kaygı gütmeden nesnel olarak incelemesi olarak algılamaktadır. Ancak Tekeli, bu durumun devletin hedeflerine ve toplumsal taleplerine duyarsızlık anlamına gelmediğini belirtmektedir. Tekeli'ye göre üniversite özerkliğini koruyarak, topluma hizmet etmelidir. Tekeli'ye göre üniversite, uzun erimli eleştiri ve değerlendirme yaparak, pragmatik kayg1lardan uzak bir şekilde meseleleri ele alırsa, toplumun ezilen kesimlerinin taleplerini dile getirebilir ve demokrasinin bekçisi olabilir. Üniversite devlete ve topluma duyarlılığı, hiyerarşik bir sistemde emir komuta zinciri içinde olmadan gerçekleşmelidir. Tekeli' ye göre, üniversite fildişi kulesinde, belirli bir mesafede toplumun sorunlarına daha nesnel olarak eğilirse, bu özerkliğin topluma katkısı yüksek olacaktır. Topluma duyarlılık adı altında piyasa güçlerinin, kendi istek ve taleplerini üniversiteye taşıması üniversiteyi bir 'kale' haline getirir ve bu toplumun daha güçüz kesimlerinin sorunlarını dile getirmesini engeller (Tekeli, 1989, s.10).

Tekeli, üniversiteyi ve üniversiteye içkin temel özelliklerini tartışırken Alman geleneğine odaklanmakta ve Humboldt geleneği üzerinden tekçi bir üniversite tarihi okuması yapmaktadır. Ancak, üniversite tarihi incelendiğinde ABD ve İngiltere' de üniversitelerin tarihsel olarak gelişimi, yönetimi, üniversiteye atfedilen önem gibi hususların Alman geleneğinden farklılaştığı 
görülmektedir. Tekeli, üniversitelerin tarihsel gelişimindeki ve yönetimindeki ülkelere göre olan bu farklılaşmaya çalışmalarında değinmemiştir. Tekeli, Alman geleneğindeki kurumsal özerkliği genelleştirerek okumuştur. Ancak, bu hususlar farklı ülkelerin üniversitelerinin tarihinde farklı anlamlara sahiptir. Örneğin, $A B D$ 'de üniversitelerin kurulma ve gelişme süreci Avrupa'dan daha farklıdır. ABD'de üniversiteler kurulurken "vatandaş yönetimi" yaklaşımı benimsenmiş ve üniversiteler kendilerini fonlayan topluma karşı çok daha fazla sorumlu hissetmiş ve hesap verir bir durumda olmuştur (Gür, 2016).

\section{Mütevelli Heyeti ve Özerklik İlişkisi}

Tekeli'nin üniversite yönetiminde mütevelli heyeti meselesini 7307 sayılı Orta Doğu Teknik Üniversitesi Yasasının Anayasaya Aykırılığı İddiası başlıklı metninde ele almıştır. Bu metin, ODTÜ Mütevelli Heyeti tarafından sözleşmesinin iptal edilmesinden sonra ODTÜ yasasının Anayasaya aykırı olduğuna yönelik hazırladığı hukuki mütalaadır. Bu metin, sadece bir hukuki mütalaa metni değil, ayn zamanda Tekeli'nin mütevelli heyeti ve özerklik konusundaki ilkesel tutumunu da ifade etmektedir (Tekeli, 2010a). Tekeli, ODTÜ'nün özel bir yasa ile mütevelli heyeti eliyle yönetilmesini 1961 Anayasasının özerklik ilkesine aykırı olduğunu belirtmekte (Tekeli, 2010a, s. 177) ve ODTÜ'nün de diğer üniversiteler ile birlikte aynı yasaya tabi olarak özerk üniversite haline gelmesini istemektedir. Ona göre bilimsel özerklik için yönetimsel özerklik önkoşul olarak ele alınmalıdır. Buna ilaveten, öğrencilerin yansız olarak yetişmesi ve belirli bir siyasal gücün etkisinde kalmaması için de özerklik gereklidir (Tekeli, 2010a, s. 180).

Tekeli, ODTÜ Yasasında mütevelli heyeti üyelerinin üniversitede kesinlikle görev almaması durumunu şu şekilde eleştirir: 1. Mütevelli heyeti tamamen siyasal iktidar tarafından belirlenirse eğitim yansız gerçekleşmez. 2. Mütevelli heyeti siyasal iktidar tarafindan kurulduğundan dolayı mütevelli heyeti rektör, dekan ve bölüm başkanını öğretim üyelerinin katkısı olmadan seçmesi, tüm üniversite yönetiminin siyasal etkilerle kurulduğu anlamına gelmektedir. 3. Bu ise mütevelli heyetinin üniversiteyi siyasallaştıran ve öğretim üyelerinin eğilimlerine ters düşen yöneticileri atamasını kolaylaştırır. 4 . Üyeler, üniversite dişından seçildiğinde üniversite ile bağ kuramamaktadır. Tekeli, ODTÜ'nün atanmış bir mütevelli heyeti tarafından yönetilmesini doğrudan siyasal organlarca yönetilmesinden daha sakıncalı bulmaktadır. 
Çünkü siyasal iktidarın halka hesap verebilirliğinden dolayı keyfi davranması güçken, küucük bir yarar grubu olan mütevelli heyetinin ise oto kontrol mekanizması olmadığından dolayı aldığı kararlarının siyasi bir bedeli yoktur. Böyle bir durumda üniversite üstünde hiçbir sorumluluğu olmayan bu grup hükümranlığın ilan etmektedir. Üniversite ile ilgili tüm yetkilerin mütevelli heyetinde toplanması, mütevelli heyetinin siyasal güçler tarafından seçilmiş olmasının sakıncasını daha da artırmaktadır (Tekeli, 2010a, s. 177-192).

Mütevelli heyetinin nasıl konumlandırıldığı, mütevelli heyetine atfedilen önem, görev ve sorumlukların dünyadaki uygulamaları ile Türkiye tecrübesi arasında önemli bir farklılık vardır. Açıkçası, dünyada uygulanan mütevelli heyeti uygulamaları Tekeli'nin anlattı̆̆ Türkiye tecrübesinden çok daha farklıdır. Yükseköğretim alanındaki birçok saygın ülkenin yükseköğretim sisteminin yönetimine bakıldığında farklı isimlere, görevlere ve işlevlere sahip olsa da bir heyet tarafından yönetildiği görülmektedir (Fielden, 2008; Gür, 2016; Kurt, 2015). Bu sistemlerde mütevelli heyeti benzer yapılar, üniversiteleri, toplum ve hükümet ve kurucular adına yönetmektedir (AGB, 2010; Martorana, 1963). Bu heyet, kuruculara ve topluma karş1 sorumludurlar. Ülkelerin yükseköğretim sistemleri yönetimine bakıldığında senato, rektör ve mütevelli heyeti arasında şu tür bir rol ve görev paylaşımı vardır: Senato, çoğunlukla akademik konularla ilgili kararlar alan ve akademik konularda mütevelli heyeti ve üniversite yönetimine danışmanlık yapan bir organdır. Rektör ve üniversite yönetimi ise senato ve mütevelli heyetinin aldığı kararları uygulayan yürütme organıdır. Mütevelli heyetinin akademik konularda sürece doğrudan müdahil olması istenilen bir durum değildir (Kurt, 2015).

Özellikle Kuzey Amerika ve Avrupa ülkelerinde mütevelli heyeti tarzındaki kurulların varlığının nedeni, toplum ile üniversite arasında güçlü bir bağın kurulması, toplumun üniversite üzerinde söz sahibi olması ile ilgilidir. Bu kurullar üniversite öğretim üyelerinden ziyade toplumun farklı kesimlerindeki kişilerden oluşur. Çünkü bu şekilde üniversiteler daha şeffaf, hesap verebilir ve toplumsal taleplere duyarlı bir hale gelir. Bundan dolayı dünyada üniversite dışındaki kişilerin yönetimde bulunduğu mütevelli heyetleri uygulaması yaygınlaşmaktadır (Çelik ve Gür, 2014; Fielden, 2008). Türkiye'de mütevelli heyeti sisteminin uygulamasının bir yanı ile hesap verebilirliği ve şeffaflığı artıracağı, tek adamlık sitemini ortadan kaldıracağı gibi olumlu değerlendirmeler yapılırken diğer yandan üniversitelerdeki siyasal etkiyi ve patranoj ilişkilerini geliştireceği konusunda bir korku vardır (Kurt, Gür ve Çelik, 2017). 
Yukanda da ifade edildiği gibi ODTÜ mütevelli heyeti tecrübesi ile dünya tecrübesi birbirinden oldukça farklıdır. ODTÜ'de Kemal Kurdaş'ın rektörlügünün sona ermesinden 12 Eylül'e kadar geçen sürede mütevelli heyeti üyelerinin birkaç kez tamamı görevden alınmış, değiştirilmiştir. Bu süreçte mütevelli heyetini özellikle rektör seçim döneminde öğretim üyeleri ve öğrencilerin taleplerine karşı duyarsız kalmış ve sürekli bir gerilim ve çatışma yaşanmıştır. 1970'lerdeki toplumdaki ve üniversitelerdeki çatışmalar, siyasal istikrarsızlık ve gerginlik mütevelli heyeti tecrübesini doğrudan etkilemiştir.

\section{İdari özerklik vs. akademik özgürlük}

Tekeli üniversite özerkliğini idari anlamda özerklik ekseninde açklamakta ve akademik özgürlük kavramını öne çıkarmamaktadır. Bu durumun gerekçesini Tekeli şu şekilde açıklamaktadır: "Temelde düşünce ve ifade özgürlüğü olan akademik özerklik sadece akademisyenlere ilişkin bir özgürlük alanı değil, günümüzde bu özgürlüğe her yurttaşın sahip olması gerekiyor... Bütün yurttaşların üniversitelerdeki hocalar kadar özgür olması gerek. Bu nedenle üniversitenin aslında akademik özerklik talebi yalnız kendisi için değil bütün yurttaşlar için olmalıdır." (Tekeli, 2011 s. 207). Tekeli, bir başka metninde "Kurumsal özerklik, akademik özgürlük gerçekleştiği zaman anlam kazanır. Akademik özgürlüğün güvencesi haline gelmeyen bir kurumsal özerkliği savunmak zorlaşır." şeklinde yazmıştır (Tekeli, 2011, s.224).

Özerklik Türkiye'de yöneticilerin seçimine indirgenirken dünyada çok daha geniş bir bağlama oturtulmaktadır. Avrupa Üniversiteler Birliği (AÜB) ve Ekonomik İşbirliği ve Kalkınma Örgütü (OECD) özerklik ile ilgili tanımlamalar yapmışlar ve bir endeks geliştirmişlerdir. AÜB özerkliği akademik, finansal, örgütsel ve istihdam özerkliği ekseninde tanımlamıştır (Estermann, Nokkola, \& Steinel, 2011). OECD'nin özerklik ölçütlerinde ise kendi binası ve ekipmanlarına sahip olma, borç alma, bütçeyi kendi hedeflerini gerçekleştirmek için kullanma, akademik yapıları kurma ve müfredatı belirleme, akademik personeli istihdam etme ve işten çıkarma, ücretleri belirleme, öğrenci sayısına karar verme ve öğrenci harç miktarını belirleme olarak tanımlamaktadır (OECD, 2003). Bu özerklik kıstasları içinde rektörlerin öğretim üyeleri tarafından seçilmeme durumu özerklik bağlamında değerlendirilmemektedir. Rektörler artık meslektaşları arasında birinci olan, profesyonel yönetici olmuş ve öğretim üyelerinin seçimi ile değil, tamamımın ya da çoğunluğun dış üyelerden oluştuğu mütevelli heyetleri tarafından atanmaya başlamıştır (Bleikle 
ve Kogan, 2007). Yükseköğretimde dünyanın önde gelen hemen her ülkesinde rektörler artık seçim ile değil, atama ile gelmektedir (de Boer \& File, 2009; Fielden, 2008). Rektörün belirlenmesinde yaşanan bu değişim, dünyada üniversite özerkliğinin sonuna gelindiği şeklinde okunmamış ve özerklik bağlamında ele alınmamıştır.

Tekeli, Humboldt tarzı üniversitenin temel özelliklerini tartışırken, bu üniversite tipinin akademik özgürlüğü nasıl kurumsallaştırdığı boyutunu incelememiştir. Humboldt tarzı üniversitede idari özerklik kadar akademik özgürlükte son derece önemlidir. Akademik özgürlük kapsamında iki kavram ön plana çıkmıştır: Öğretim özgürlüğü (Lehrfreiheit) ve öğrenim özgürlüğü (Lernfreiheit) (O'Neil, 1999). Bu kavramlar bir yandan öğretim üyelerinin özgürce araştırma yapmasını ve ders vermesini ifade ederken, diğer yandan da öğrencilerin öğrenim özgürlüğünü ifade etmektedir. Alman üniversite geleneğinde bu iki kavram öğretim üyelerinin sınıf içinde ya da araştırma ortamlarında öğretme özgürlügünü ve öğrencilerin de baskıya maruz kalmadan öğrenme özgürlügünü ifade etmektedir (Albatch, 2001). Öğretim üyelerinin neyi, nasıl öğretecekleri ve araştırma konusunu seçme hususundaki özgürlükleri akademik özgürlük olarak tanımlanır. Bu durum öğretim üyelerinin dıştan müdahale olmadan araştırma ve öğretim yapması demektir. Bu sınırsız bir özgürlük anlamına gelmemektedir. Öğrenim özgürlüğü ise öğrencilerin idari, siyasi baskılardan uzak, sınıfta konuşma ve araştırma özgürlügüüü ifade etmektedir (Down, 2009).

Akademik özgürlük ile ilgili en önemli belgelerden biri de ABD'de Amerikan Üniversite Profesörleri Birliği (AÜPB)'nin 1915 yılında yayımladığı Akademik Özgürlük ve Akademik Daimi Kadro (Tenure) İlkeleri Deklarasyonu'dur. Deklarasyon, ABD'de öğretim üyelerinin iş güvenliği açısından zorluk yaşadığ bir dönemde ortaya çıkmış ve öğretim üyelerini öğrencilere daha etkili ve faydalı eğitim sunmak için akademik özgürlüğü garanti altına alan iş güvenliği sisteminin gerekli olduğunu vurgulamıştır. Deklarasyon akademik özgürlüğün üç temel unsuru olduğunu belirtmiştir: 1- soruşturma ve araştırma özgürlüğü; 2- üniversitede veya kolejlerde öğretim özgürlüğü; 3- sınıf/üniversite-dışı (extramural) söz ve eylem özgürlüğü (AAUP, 1915). Bu belgedeki en kritik husus, akademisyenlerin sadece üniversite, sinıf ya da araştırma ortamlarında değil, bu ortamların dışında da söz ve eylem özgürlüğünü vurgulamaktadır (Albatch, 2001). Diğer bir kritik husus ise bu belgede öğrenim özgürlüğü ihmal edilmiştir. 1940 ve 1967 tarihli belgelerinde AAUP akademik özgürlük kavramını daha da kurumsallaştırmış ve öğrenim 
özgürlüğünü de akademik özgürlük içine dahil etmiştir. Bu belgeler, akademik özgürlüğün sınırsız olmadığını, dersin konusu ile ilgili olmayan hususların derste anlatılmaması gerektiğini belirtmektedir. Dersler disiplinin gerektirdiği ilkeleri dikkate alarak ve etik çerçevede gerçekleştirmeli, derslerde propaganda yapılmamalı, öğretim üyeleri kendi görüşlerini endoktrine etmemeli ve kendi öznel görüşlerini hakikat olarak sunmamalıdır. Kısacası akademisyen, araştırma yaparak hakikatin peşinde koşmalı ve bu araştırmaların profesyonel ilkeler ekseninde öğrencileri ile paylaşmalıdır (Seggie ve Gökbel, 2014). Akademik özgürlük ile ilgili en kritik mesele üniversite-dışı konuşma özgürlüğüdür, akademisyen sansür ve ceza korkusu olmadan konuşabilmelidir. Ancak bu bireysel ifade özgürlügünden daha da dar bir çerçeveyi kapsamaktadır (Downs, 2009). Bir akademisyen konuşurken dikkatli olmalıdır. Örneğin; Koronavirüs hakkında sıradan bir vatandaş istediği gibi saçma bir argüman sunabilir ama bir tıp profesörü ise ifade özgürlüğü kapsamında sorumsuzca ifadeler kullanamaz. Çünkü onun kullandığı ifadeler, sahip olduğu unvan ile insanları yanlış yönlendirebilir.

Kısacası, Tekeli Türkiye'deki yükseköğretim tartışmaları içinde idari özerkliği Humboldtçu bir çizgi içinde üniversite olmanın en önemli özelliği olarak tanımlamış ve tartışmalarının odağına idari özerklik mevzusunu almiştır. Diğer taraftan Tekeli, akademik özgürlük meselesinin nasıl geliştiğini ve Türkiye'deki seyrini ise incelemelerinin dışında bırakmıştır.

\section{Akademik Özgürlüğün Önündeki Engeller: Aşırı Güçlü Ve Yetkili Rektörler}

Tekeli, her ne kadar üniversite özerkliğinin en önemli göstergesi olarak rektörün öğretim üyeleri tarafından seçilmesi olduğunu ifade etse de Türkiye'de rektörlerin öğretim üyeleri tarafından seçilmesinin neden olduğu risklerin de farkındadır. Bu riskleri Tekeli şu şekilde açıklamaktadır: Üniversitelerdeki seçimler doğrudan demokrasinin delili değildir. Çünkü seçim süreçlerinde kadro dağıtımı, bir siyasi grubun parçası olma ya da fiziki baskı uygulamaları gibi hususlar rektör seçim süreçlerinde yaşanmıştır. Mevcut rektör kendisinden sonraki rektör seçim süreçlerinde aktif rol almaktadır. Hatta karısını rektör olarak seçtirenler dahi vardır. Tekeli, rektörlerin saltanat oluşturması için iki dönem seçim kazanmasının yeterli olduğunu söylemektedir (Tekeli, 2011, s. 282). Her seçim sonrasında üniversite içinde gerginlikler, sorunlar var olmakta ve yeni rektörler kendisine oy vermeyenleri eleme peşinde koşmakta- 
dır. Tekeli, üniversite yönetimlerini en önemli sorunun demokratikleşme olduğunu ve rektörlerin aşırı yetki ile donatıldığını söyler. Üniversite yönetimini demokratikleştirilmeli ve üniversitelerin "İç yönetimi bugün bulunduğu diktatörlük sisteminden kurtar[1lmalıdır]." (s.283).

Türkiye'deki rektörlük seçimleri rektörlerin sahip olduğu aşırı güce de bağlı olarak Tekeli'nin ifade ettiği gibi bazen ciddi sanclara da neden olmaktadır (Tekeli, 2011; Szyliowicz, 1994). 1970'lerdeki bu sorunlar 1990'lardan sonra rektör seçimleri tekrar başladığında yine görülmüştür. Adayların birbirine karşı oldukça sert bir kampanya yürüttüğü, üniversitede altı ay hatta bir yıl öncesinde nerdeyse hayatın durduğu, seçim gündemi nedeniyle bilimsel faaliyetlere ilginin azaldığ 1 , kadroların tahsisi seçime göre belirlendiği, kayırmacilık ve grupçuluk sorunlarının ortaya çıktığı, bu durumun ise üniversitede bölünme ve parçalanmaya hatta kamplaşmaya neden olduğu ve beraberinde rektöre oy vermeyenlerin zulme maruz kaldığı durumlar yaşanmıştır. Kısacası rektör seçimi Türkiye'de ciddi sorunlara neden olmuş ve üniversitenin gelişimi ve niteliğini olumsuz etkilemiştir (Kurt, Gür ve Çelik, 2017).

Tekeli'ye göre, özerklik konusundaki en önemli problemlerden biri de aşırı güçlü ve olağanüstü yetkilere sahip rektörlerin varlığıdır. Öğretim üyelerinin özgürlügünden ve katılımcı bir yönetimden bahsetmek mümkün değildir. Senato ve fakülte kurullarının rektör ya da dekan karşısında yeterli güce sahip değildir. Tekeli, böyle bir üniversitenin özerkliğini artırmanın son derece sorunlu olduğunu belirtir ve ekler: "üniversite özerkliğini artırmak, yerel beylikler yaratmak anlamına gelebilecektir." (Tekeli, 2011, s. 181). Tekeli, savunduğu özerkliğin bu olmadığını vurgulamaktadır. Tekeli asıl problemi üniversite içinin özerk olmaması olarak tanımlar ve öğretim üyelerinin yönetim karşısında bir özerklik sorunu olduğundan bahseder. Bu sorunun çözümü için şunu önerir: "Üniversitenin demokratikleşmesi için rektörlerin gücünü azaltan, rektörlerin karşısında yeni ağırlıklar oluşturan, üniversite içi güç dağılımını çok merkezli hale getiren bir gelişmeye ihtiyacımız var." (Tekeli, 2011, s. 282).

Tekeli'nin de ifade ettiği gibi Türkiye'de yükseköğretim sisteminde rektör çok güçlü bir konuma sahiptir. Yükseköğretim Kanunu'nun 13. maddesine göre rektör hem idari yönetimin hem de akademik senatonun başı olarak tanımlanmıştır. Üniversitedeki kurullar yeterince etkin çalışmamaktadır. Yükseköğretim kurumlarını üst düzey yöneticileri ile yapılan çalışmada rektörün hem senatonun hem de idari yönetimin başı olması, nihai karar vericinin rektör olmasına ve üniversitenin rektörün taleplerine göre şekillenmesine neden olduğu bulunmuştur(Kurt, Gür ve Çelik, 2017). Dahası, öğretim üyeleri 
bu kurullarda kendi görüşlerini rahat bir şekilde dile getirememektedir. Burada özellikle kadro tahsisinde ve bazı yatırımlara öncelik verme konusunda rektörün sözü geçmektedir. Kurullar, rektörlerin etkisi altında olduğundan dolayı üniversitelerde aşırı hiyerarşik ve rektör merkezli bir yapı ortaya çımaktadır. Buna ilaveten, rektörlerin buyurgan bir tavır içinde olduğu, müzakereci ve uzlaşmacı bir dil kullanmadığı, yetkilerini ve sorumluluklarını paylaşmadığı, hatta birden çok görevi (bazı fakültelerin dekanlığı gibi) uhdesinde tuttuğu görülmektedir (Kurt, Gür ve Çelik, 2017). Rektör, kurulların üzerinde tanımlandığından dolayı kurullar rektörü denetleme ve gücünü dengeleme rolünü üstlenememektedir. Sahip oldukları güç ile Türkiye'deki rektörler ABD, İngiltere, Almanya ya da Fransa gibi birçok ülkedeki başkan/rektörlerden çok daha fazla yetkiye sahiptir. Bu ülkelerde senato ya da mütevelli heyeti karar alma, rektör ise icradan sorumludur. Türkiye'de ise hem karar alma hem icra yetkisi rektöre aittir (Küçükcan ve Gür, 2009; Kurt, 2015). Türkiye'de üniversitelerin topluma karşı hesap vermemeleri ve demokratik olmamaları nedeniyle rektörlerin öğretim üyelerinden oluşan kurulları dikkate alıp almadığı kişisel takdirine kalmaktadır. Açıkçası, bu sorunların sadece bazı yasal düzenlemeler ile çözülmesi beklenmemektedir (Seggie ve Gökbel, 2014).

\section{3 Üniversite Reformundan YÖK'un Kuruluşuna: Özerkliğin İmkânı}

Tekeli'ye göre, 1933 Üniversite Reformu ile birlikte Türkiye'de üniversite Humboldtcu modele göre kurulmasına rağmen üniversite Millî Eğitim Bakanlığı'na bağlanmıştır. 1946 yılında kabul edilen 4936 sayılı Üniversite Kanunu ile fakültelerin ve üniversitelerin tüzel kişilikleri kabul edilmiş ve üniversiteler özerk yapıya sahip olmuştur. Bu kanun ile meslektaş yönetimi anlayışı benimsenmiş rektör ve dekanlar seçim ile belirlenmeye başlamıştır. Milli Eğitim Bakanı üniversiteler arası kurulun başkanı olarak denetleme ve görev yetkisi ile meclise karşı üniversite işlerinden sorumlu kılınmıştır. Bu kanun ile Türkiye' deki üniversitelerin Humboldt tarzında kurulması tamamlanmıştır (Tekeli, 1994, 2019).

Tekeli'ye göre Demokrat Parti (DP) özerk üniversite anlayışından rahatsızlık duymuş ve özerklik anlayışına karşı bir mücadeleye girmiştir. 1954'te Kanunda yapılan değişiklik ile Milli Eğitim Bakanına senato görüşü sonrasında öğretim üyelerini görevden alma yetkisi verilmiştir. Tekeli, DP döneminde bu tarihlerden sonra kurulan yükseköğretim kurumlarına özerklik ve- 
rilmediğini belirtmektedir. Örneğin; ODTÜ ayrı bir yasaya tabi olarak mütevelli heyeti ile yönetilirken yeni kurulan akademiler ise özerk olmayan yapılar olarak kurulmuştur (Tekeli, 2019, s.290). 1961 Anayasası ile üniversitelere geniş bir özerklik tanınmıştır. Tekeli, Türkiye'deki akademisyenlerin ideal üniversite yönetimi anlayışının 1946 Üniversite Kanunu ile 1961 Anayasası tarafından belirlendiğini söyler (Tekeli, 2012).

YÖK'ün kurulmasından sonra yükseköğretim sisteminde bazı önemli değişimler yaşanmıştır. 1961 Anayasası ile üniversitelere tanınan sınırsız özerklik sona ermiş, artık üniversiteler sadece bilimsel özerkliğe sahip olmuştur. Rektörler ve dekanlar öğretim üyelerinin seçimi ile değil, atama ile belirlenmeye başlanmıştır. Dahası, kanunun ilk hallerinde fakülte kurulları, senato gibi kurulların ağırlığı azaltılmış ve bu yetkiler dekan ve rektöre verilmiştir (Tekeli, 2010a). YÖK'ün ilk kurulduğu dönemde bölümlere merkezden gönderilen programlar dayatılmaya çalışılmış, YÖK dersleri olarak Türkçe ve İnkılap Tarihi dersleri konulmuş, öğretim üyesi ve öğrenciler için kılık kıyafet kuralları getirilerek sakal ve başörtüsü yasağı uygulanmıştır (Tekeli, 2010a; 2019).

Türkiye yükseköğretim tarihine bakıldığında akademik özgürlük ve üniversite özerkliği mevzusu, üniversite yöneticilerinin kim olması gerektiği konusuna indirgenmiştir. Üniversiteyi kimin yöneteceği konusunda oldukça hassas davranan Türkiye akademisinin akademik özgürlükler konusu ile ilgilenmedikleri görülmektedir (Çelik ve Gür, 2014; Gür ve Çelik, 2011). Modern üniversite tarihinde akademik özgürlükleri kısıtlayan birçok olay yaşanmasına rağmen akademik özgürlüğün ne olduğu yeterince tartışılmamıştır. Türkiye'de üniversite kurulurken tasfiye ile kurulmuş (Tunçay, 1984) ve üniversite tarafsız olmayacağını ve rejime sadık olduğunu daha kuruluşunda ifade etmiştir (Bilsel, 1943). 1946'da çıkan Üniversiteler Kanunu ile üniversiteler özerk ve tüzel kişiliğe sahip iken kendi yöneticilerini seçme özerkliğini kazanan üniversiteler bu özerkliği akademik özgürlüğü geliştirmek için değil, kendi kurumsal özerkliğini korumak için kullanmışlardır (Gür ve Çelik, 2011; Çelik ve Gür, 2014). Bu dönemde yaşanan iki olay üniversitenin yönetimsel ve akademik özgürlüğe bakışı açısını oldukça açılayıcıdır. İlki, üniversiteler öğrenci seçimi konusunda hükümetin talebini üniversiteye müdahale olarak algilarken Ankara Üniversitesi'nde sol görüşe sahip öğretim üyelerinin komünizm propagandası yaptıkları, siyasi telkinlerde bulundukları gerekçesi ile Ankara Üniversitesi Senato kararı ile 1948 yılında üniversitenden uzaklaştırılmıştır (Seggie ve Gökbel, 2014). 
Benzer şekilde 1960 askeri darbesi sonrasında 114 sayılı Kanun ile 147 öğretim üyesi üniversiten uzaklaştııılırken aynı gün çkarılan 115 sayılı Kanun ile Bakanlık emrine alma yetkisi iptal edilmiştir. 1960 Anayasası ile üniversitelerin öğretim üyeleri tarafından seçilen kişilerce yönetilmesi idari özerkliğe sahip olan üniversitelerde öğrenci olayları kapsamında üniversitelerde derslerin engellenmesi ve sınıfların işgali, öğrenim özgürlügünü sınırlayan bir olay olmasına rağmen bu yönde bir değerlendirme yapılmamış üniversite özerkliği ve öğrenci özgürlüğü denilerek övgü dolu dizeler düzülmüştür (Gür ve Çelik, 2011, s. 13). 12 Eylül Askeri Darbesi sonrasında birçok kişi üniversiten ihraç edildiğinde Doğramacı, YÖK ve YÖK'ün geniş yetkileri eleştirilmiş fakat akademik özgürlükler yine ana tartışma konusu olmamıştır. 28 Şubat sonrasında başörtüsü, imam hatip mezunlarının üniversiteye girişi bazı rektörlerin görevden alınması ne üniversite özerkliğine müdahale ne de akademik özgürlük bağlamında ele alınmamıştır. Daha ilginci seçilmiş bir iktidarın yükseköğretim reformu yapma çabası yoğun bir şekilde eleştirilirken Gürüz ve bazı rektörlerin askerleri destek için ziyareti özgürlük ve özerkliği sinurlayan bir husus olarak değerlendirilmemiştir (Çelik ve Gür, 2012).

Tekeli ise üniversitelerden tasfiye meselesini eleştirmiş, 1948 yılında Ankara Üniversitesi'nden öğretim üyelerinin tasfiyesini, üniversitenin kendisine verilen özerkliği "hak etmediği" şeklinde yorumlamıştır (Tekeli, 2010a, s. 170). Benzer şekilde 12 Eylül Askeri Darbesi ve YÖK'ün kuruluşu sonrasındaki tasfiye ve üniversite özerkliğine yönelik müdahalelere karşı oldukça sert tepki vermiştir.

\section{YÖK ve Sorunları}

Tekeli'ye göre, 60'lı yıllardan itibaren üniversitelerin özerkliği iyi kullanmaması ve özellikle yükseköğretime yönelik artan talebe karşı duyarsız kalması, yükseköğretime yönelik arz-talep arasındaki büyük fark; üniversiteler, akademiler ve MEB'e bağlı yükseköğretim kurumlarının yükseköğretim sistemine yönelik bütüncül bir bakış açısıyla meselelere odaklanmaması; üniversitelerin öğrenci hareketleri sonrasında kendisini dönüştürme dinamiğine sahip olmaması, Humboldtcu kürsü profesörlüğü uygulamasındaki profesörlerin sorunlarla yeterince ilgilenmemesi, 1961 Anayasası ile birlikte özerk üniversite anlayışının sorunları görmesini engellemesi; üniversitenin kendisini yeniden üretemeyişi, toplumun beklentilerine yanıt veremeyişi ve kendi 
içinde yaşadığı bölünmeler, 1960 sonrasında elde ettiği saygınlığı kaybetmeye başlaması gibi hususlar YÖK'ün kuruluşunu hazırlamıştır (Tekeli, 2010a, 2019).

Tekeli'ye göre, YÖK ile birlikte; yukarıda özerklik bağlamında tartışılan değişikliklere ilaveten, yükseköğretimde disiplin ve süreklilik sağlanmış; üniversitelerde özerklik çok yönlü zedelenmiş; yabancılaşma artmış; öğretim üyelerinin iş güvenceleri önemli ölçüde aşınmış; YÖK'ün uygulamaları sonrasında akademik faaliyetler önemli ölçüde üniversite dışına kaymış; öğretim elemanı yetiştirme geleneği büyük ölçüde tahrip olmuş; yükseköğretime ilişkin kurallar tam bir yapboza dönüşmüştür. Buna ilaveten, öğrenci sayısı artmış, yükseköğretime yönelik arz-talep arasındaki fark azalmış, üniversite sayısı artmış, tecrübeli öğretim üyelerinin üniversiteden ayrılmasına rağmen öğretim üyesi sayısı artmış ve ülke sathına görece daha iyi dağılmıştır (Tekeli, 2010a).

2547 sayılı Yükseköğretim Kanunu ve YÖK'ün kurulması yükseköğretim sisteminde oldukça kritik bir değişime neden olmuştur. 1946 ve 1973 tarihli üniversite kanunları bilimselliği ve bilimsel öğretimi ilk amaç olarak tanımlamıştır. Ancak mevcut yükseköğretim kanununun amaç ve ilkelerine bakıldığında, çok açık bir şekilde kanun bilim, araştırma, akademik özgürlük gibi tüm ifadeleri yükseköğretimin en son amacı olarak tanımlamış, ilk amaç olarak Atatürk inkılapları, Atatürk milliyetçiliği, Türk milli, manevi ahlakı ve devlete karşı görevleri gibi hususlar sıralanmıştır. Kanun üniversiteleri bilimin üretildiği ve öğrenildiği bir kurum olarak değil, insanları belirli bir ideoloji ve dogmalar ekseninde sslah etmeyi hedefleyen bir kurum olarak tanımlamıştır (Gür ve Çelik, 2011; Küçükcan ve Gür, 2009).

Yükseköğretim tarihi içinde 40 yıllık YÖK deneyimi kalite, akademik özgürlük, bilim ve araştırma adına birçok olumsuzluğun yaşandığ 1 dönem olmuştur. Anayasal bir statüye sahip olarak kurulan ve başkan merkezli olarak tasarlanan YÖK, bugüne kadar tartışmaların odağında olmuş ve toplumsal taleplere cevap üretememiştir. YÖK'ün politika ve uygulamalarını belirleyen en temel husus YÖK başkanının ve üyelerinin çoğunluğunun cumhurbaşkanı tarafından atanmasıdır. 12 Eylül sonrasında YÖK tasarlanırken, siyasetin hesap verebilir olmayan kişisi olan cumhurbaşkanının YÖK başkanı ve üyelerinin çoğunu ataması tasarlanmıştı (Gür ve Çelik, 2011). YÖK anayasal statüye sahip olduğundan kendi özerkliğini siyasal iktidara karşı koruyabilmekte ve siyasal iktidara rağmen yapmak istediklerini yapmakta ya da siyasal iktidarın taleplerini dikkate almamaktaydı. Buna ilaveten, oldukça yetkili 
ve güçlü bir organ olan YÖK her ne kadar bir kurul olarak tanımlansa da başkan merkezli bir yapıya sahiptir. Çünkü YÖK'ün özerkliğinin ve anayasal statüye sahip olmasının YÖK ve başkanına oldukça büyük güç vermektedir. Bundan dolayı da her YÖK başkanı döneminde farklı bir politika ve uygulama ile karşılaşılmıştır (Tekeli, 2010a, 2010b).

Cumhurbaşkanları, hükümet ve YÖK başkanları değiştikçe YÖK'ün politika ve uygulamaları da değişmiştir. Cumhurbaşkanı ve hükümetler, toplumda çatışmadan uzak tavırlar izlediği dönemde YÖK uzlaşmac bir politika takip ederken, çatışmanın ya da baskının olduğu dönemde hemen bu rolü benimsemiş ve üniversiteler de kendilerine bu ortamdan gerekli payı çıkarmışlardır. Açıkçası, Cumhurbaşkanı'nın doğrudan halk tarafından seçilmeyip, hesap verebilirliğinin olmaması YÖK politikalarını etkileyen bir unsur olduğu düşünülmektedir. Bir taraftan halk tarafından seçilen Cumhurbaşkanının daha hesap verebilir olacağından dolayı yükseköğretimde normalleşmeye katkı yapacağı ifade edilirken (Gür ve Çelik, 2011) diğer taraftan ise halk tarafından seçilen Cumhurbaşkanının, YÖK başkanı ve üniversite rektörlerini atamasının zaten aşırı hiyerarşik bir yapıya sahip olan ve siyasal kutuplaşmanın odağında olan yükseköğretim alanını daha da siyasallaştıracağı vurgulanmıştır (Ergüder vd., 2009). Açıkçası Abdullah Gül'ün Cumhurbaşkanlığı ile Yusuf Ziya Özcan ve Gökhan Çetinsaya'nın YÖK Başkanlığı dönemindeki YÖK ve üniversiteler normalleşme sürecine girmiştir. Her iki başkan da yükseköğretim reformu talep etmiştir. Özcan, YÖK'ün kaldırılması gerektiğini ifade ederken, Çetinsaya döneminde iki yıl süren yeni yükseköğretim yasası hazırlanmıştır. Hatta Çetinsaya döneminde ilk kez bir YÖK Başkanı Akademik Özgürlük Bildirisi yayınlamıştır (Seggie ve Gökbel, 2014). Ancak yükseköğretimdeki bu pozitif süreç kısa sürede son bulmuş ve Tekeli'nin ifadesine göre, mevcut iktidar için artık YÖK eleştirilen bir kurumdan sahip çıkılması gereken bir kuruma dönüşmüştür (Tekeli, 2019).

\section{Üniversite Sorunu ve Reform Söylemi}

İlhan Tekeli 1970'lerden itibaren üniversite sorununun kronik bir şekilde Türkiye'nin gündeminde olduğunu ve çözülmeden halen güncelliğini koruduğunu belirtmektedir (Tekeli, 1994, 2010b). Tekeli'ye göre üniversite sorunun gündemde olmasının iki temel nedeni vardır. İlki siyasal iktidar ile üniversite öğretim üyelerinin arasındaki uyuşmazlıktır. Bu uyuşmazlıktan her iki taraf da sorumludur. Siyasal iktidar özellikle 1970'li yıllardaki üniversite olayla- 
rından dolayı üniversiteleri denetim altında tutmak istemektedir. Buna ilaveten, siyasal iktidar halkın yükseköğretim talebini karşılamak için üniversite öğrenimi gören öğrenci sayısını çoğaltmaya, bunun içinde üniversite sayını artırmaya ve tüm ülke sathında yaygınlaştırmaya çalışmaktadır. Tekeli'ye göre, siyasal iktidarın bu iki temel politikası üniversite öğretim üyelerindeki yerleşik olan üniversite anlayışına uymamaktadır. Özellikle 1960'lardan itibaren gelen üniversite özerkliği ve üniversiteden beklenen kaliteli eğitim anlayışı ile çelişmektedir. Tekeli, üniversite öğretim üyelerinin hem kendi taleplerini hem de ülkenin taleplerini karşılayacak bir üniversite modelini konsensüs ile ortaya koyamadığını belirtmektedir (Tekeli, 1994). Tekeli'ye göre, yükseköğretimin sorunlarının çözülmemesinin diğer nedenini ise öğretim üyelerinin yaptıkları işe aşırı önem vermesi ve toplumun da üniversitenin, ekonomik, toplumsal, siyasal, kültürel vb. alanlarda karşı karşıya kalınan sorunların çözümünü sağlayacak temel unsur olarak görülmesinden kaynaklanmaktadır. Üniversite, kendi sorunları üzerine bilimsel araştırmalar yapmamış ve çözüm üretmemiş, gerçekçi taleplerde bulunmamış ve çözümler üzerinde uzlaşlar sağlayamamıştır (Tekeli, 1994). Üniversite bunları yapamadığı için sürekli dış müdahaleler ile karşılaşmış ve bunlara da üniversite sürekli direniş göstermiştir (Tekeli, 2010a).

Tekeli (2011) tüm toplumun ve öğretim üyelerinin heyecanını paylaştığ 1 bir yükseköğretim reformuna ihtiyaç olduğunu ifade etmiştir. YÖK'ün kuruluşundan beri, Türkiye yükseköğretim sisteminin aşırı merkeziyetçi olduğu, üniversitelerin özerkliklerinin sınırlı olduğu ifade edilmiş ve üniversitelerin özerkliklerini artıracak, YÖK'ün yetkilerini azaltacak ve YÖK'e sadece eşgüdüm rolü verilecek bir reform gerçekleştirilmesi gerektiği vurgulanmıştır (Çelik ve Gür, 2014; Ergüder vd., 2009; Gür ve Çelik, 2011; World Bank, 2007; YÖK, 2007). Hatta YÖK eski başkanlarından Yusuf Ziya Özcan YÖK'ün kaldırılması gerektiğinden bahsetmiştir (Gür ve Çelik, 2011; Tekeli, 2019). Buna ilaveten, Gökhan Çetinsaya'nın YÖK başkanlığı döneminde yaklaşık iki yıl süren yeni yükseköğretim yasası çalışmaları yürütülmüştür. Ancak bu çalışmalar yasalaşmamıştır. Yekta Saraç'ın YÖK başkanlığı döneminde reform söylemi terk edilmiş ve yeni bir yükseköğretim yasası çalışması yapılmamıştır. Saraç, yükseköğretimin sorunlarının yasalardan değil, uygulamalardan kaynaklandığını vurgulamıştır. Bundan dolayı yeni bir yasaya gerek olmad1ğını belirtmiştir (“Saraç: YÖK yasası...", 2014). 


\section{Yükseköğretimde Büyüme ve Kalite Meselesi}

Türkiye yükseköğretimin en önemli tartışma alanlarından biri de yükseköğretim sisteminin büyümesine yöneliktir. Türkiye'deki üniversite çevrelerinde ve YÖK gibi politika yapıcılarda sıklıkla yükseköğretimin büyümesinin kaliteyi olumsuz etkilediği nedeniyle büyümeye karşı olumsuz bir tutum vardır. İlhan Tekeli, 1970'lerden itibaren farklı dönemlerde yazdığı yazılarla bu tartışmalara katılmıştır.

1972 yılında Mimarlık dergisinde yayınlanan Büyükkent Dışı Üniversitelerin Kuruluş Yeri ve Sorunları Üzerine başlıklı makalesinde büyükşehirler dışına üniversite kurma olgusuna yönelik eleştirilere cevap vermiştir. Bu yazısında Tekeli, üniversitelerin büyükşehirler haricinde taşraya kurulması meselesini sadece kamu maliyesi üzerine etkisi ya da bölgedeki harcamayı geliştirmesi gibi faktörler ekseninde değerlendirilmemesi gerektiğini belirtmektedir. $\mathrm{Bu}$ açıdan bakıldığında üniversitelerin maliyeti yüksek olabilir. Tekeli, üniversite kurulması meselesini çok daha geniş bir perspektiften, kamu maliyesi, öğretim üyeleri, öğrenciler, yerel toplum gibi unsurlar açısından fayda ve maliyetlerinin analiz edilmesi gerektiğini vurgulamaktadır. Tekeli, büyükşehir dışında üniversite kurmanın fırsatlar sunabileceğini söylemektedir. (Tekeli, 1972). Tekeli 1994 yılında Birikim dergisine yazdığı bir yazıda 1992' de kurulan üniversitelerin kurulmasının bir ihtiyaç olduğunu açık bir şekilde ifade etmektedir. Tekeli, gelişmiş ülkelerde yükseköğretime dahil olma oranının \%65'lerde olduğunu ifade etmekte ve şunu eklemektedir: “Türkiye henüz bu orana yetişememiştir. Bu nedenle Türkiye hem üniversite sayısını artırmak hem de bu üniversitelerde kaliteli bir eğitimi gerçekleştirmek durumundadır. Çözümü eski iyi günlere dönmekte arayamayız." (Tekeli, 1994, s.39).

Tekeli, yükseköğretim sisteminin büyümesini ve toplumun daha geniş kitlelerine hitap etmesi gerektiğini şu şekilde açıklamaktadır: Illk olarak değişen dünya ve ekonominin yapısı bunu gerektirmektedir. Demografik firsat penceresi açısından bakıldığında 1960'larda bir çalışana bir yükseköğretim öğrencisi düşerken 1990'lara ve 2000'li yıllara gelindiğinde her üç çalışana bir yükseköğretim öğrencisi düşmeye başlamıştır. Dolayısıyla yükseköğretime daha fazla kaynak ayırma imkânı vardır. İkinci olarak dünyadaki eğilimlere bakıldığında yükseköğretime erişim oranları \%65'ler civarına iken 2000'li yıllarda Türkiye' de bu oran \%35 civarındadır. Tekeli, öğrenci sayısını 3,9 milyona yükseltmeyi ve bunun içinde açıöğretimin oranının \%11'lerde kalması gerektiğini ve vakıf yükseköğretim kurumlarının payının ise \%16'lara yük- 
selmesi gerektiğini ifade etmektedir (Tekeli, 2011). Daha önemlisi Tekeli, üniversite eğitimi meselesini insan hakları ve eğitim hakları çerçevesinde ele almaktadır. Buna ilaveten Tekeli, yükseköğretimin herkese yönelik olmasının özellikle toplumun daha dezavantajlı kesimlerinden gelenler için önemli bir imkân sunacağını vurgulamaktadır. Dezavantajı kesimlerden gelenler yükseköğretime katıldıkları zaman dikey toplumsal hareketlilik imkanına sahip olabilecektir. Buna ilaveten, Tekeli'ye göre öğrenme insanların temel hakkı olduğundan olabildiğince kişinin yüksek eğitim alması makul bir durum olarak değerlendirir. Eğitimin bireye kattı̆̆ değer yüksek olduğundan toplum bundan faydalanır. Bundan dolayı, yükseköğretimin büyümesi gerekmektedir. Tekeli, burada kritik bir hususa değinir ve niteliği de beraberinde getirmeyen nicelik artışlarının eşitlikçi etkiler yaratmayacağını tersine eşitsizliğin yeniden üretimine neden olacağını belirtir. Bundan dolayı nicelik ve nitelik artışını birlikte düşünmek gerekmektedir (Tekeli, 1989).

Yükseköğretimde büyüme meselesine olumlu yaklaşan Tekeli, yeni üniversitelerin kalite ile ilgili sorun yaşamaması için acilen yeni öğretim üyesi yetiştirilmesi ve doktora mezun sayısının artırılması gerektiğini vurgulamaktadır. Tekeli, doktora mezun sayısının yıllık 10 bin düzeyine çıkarılması gerektiğini ifade etmektedir. Tekeli, öğretim üyesi açığını kapatmak ve doktora mezun sayısını artırmak için Türkiye'deki eski ve daha başarılı üniversitelerinin öğretim üyesi yetiştirmek için aktif rol oynamasın; yurtdışına lisansüstü eğitime öğrenci göndermeyi ve yüksek kaliteli lisansüstü öğrenciler bularak onları mali olarak desteklemeyi önermektedir (Tekeli, 1994; 2011).

Tekeli'nin yükseköğretimin büyümesi ve kalite eksenli yaklaşımını dikkate alarak, Türkiye'deki mevcut durumu incelediğimizde şu durum ile karşlaşmaktayız. Yükseköğretime yönelik talep her geçen yıl artmaktadır. Yükseköğretime geçiş sınavına başvuran aday sayısı 2010 yılında 1,6 milyon iken 2019 'da bu sayı 2,5 milyonu aşmıştır. Burada en dikkat çeken veri, sınava başvuran adayların \%25'i yani yaklaşık 650 bin kişi ya daha önce bir yükseköğretim programına yerleşmiş ya da yükseköğretimden mezun olmuş kişilerdir. Yükseköğretime yönelik talep büyürken yükseköğretim kontenjanlarında son beş yılda önemli bir artış yaşanmamıştır. Bu durumun sonucu olarak 2009 yılında sınava başvuranların \%60'1 herhangi bir yükseköğretim programına, \%21'i ise lisans programina yerleşirken bu oran 2019 yılında ciddi bir şekilde azalmış, başvuranların \%36'sı herhangi bir programa \%16'sı ise bir lisans programına yerleşmiştir. Başka bir ifade ile sınava başvuran adayların ancak üçte biri bir programa yerleşirken yedide biri ancak bir lisans 
programına yerleşmiştir. Lise son sınıf düzeyinde sınava girenlerin durumuna bakıldığ zaman arz-talep konusundaki kriz daha ciddi bir şekilde görülmektedir. Çünkü lise son sinıf düzeyindeki öğrencilerin \%30'u ancak bir programa yerleşmiştir (Çelik, Bozgeyikli ve Yurdakul, 2019). Ortaöğretimden ortalama bir milyon genç mezun olurken bunların ancak 300 bini herhangi bir programa yerleşmiş ve 700 bin kişi ise herhangi bir programa yerleşmemiş olması oldukça kritik bir durumu işaret etmektedir. Bu veri çok açık bir şekilde yıllardır kamuoyunda dile getirilen yükseköğretim kontenjanlarının lise mezunları sayısını karşılayacağı iddiasının anlamsız olduğunu göstermektedir. Yükseköğretime yönelik arz ve talep arasında oldukça büyük bir fark var olmaya devam etmektedir. Yükseköğretime yönelik büyük bir talep var olmaya devam ettiğinden yükseköğretim sisteminin genişletilmesine devam edilmelidir (Çetinsaya, 2014; Gür, Çelik \& Yurdakul, 2018; 2019; YÖK, 2007). Bu duruma rağmen, YÖK Başkanı Yekta Saraç yaptığı açıklama ile yükseköğretim sistemindeki hedeflerinin büyüme ve kontenjan artırmak olmadığını belirtmiştir (“YÖK Başkanından...", 2020). Daha açı ifade ile yükseköğretim sisteminin büyümesine yönelik olumsuz tutum başta YÖK olmak üzere toplumun ve siyasetin farklı kesimlerinde halen ciddi bir şekilde varlığını devam ettirmektedir.

Türkiye yükseköğretim sisteminin aşırı büyüdüğüne yönelik eleştiriler sıklıkla yapılmaktadır. Türkiye yükseköğretim sisteminin büyüklüğü yanıltıcıdır. Çünkü, Türkiye, yükseköğretim sistemindeki 7,7 milyon öğrencinin 3,9 milyonu başka bir ifade ile \%53,5'i açıöğretim öğrencisidir. Anadolu Üniversitesi açıöğretim programlarındaki toplam kayıtlı öğrenci sayısı (3,3 milyon) tüm devlet üniversitelerindeki yüz yüze öğretim programlarındaki öğrenci sayısından daha yüksektir. Bu ise aslında Türkiye yükseköğretim sisteminin büyüklüğünün sanal bir büyüklük olduğunu göstermektedir. Türkiye'de yükseköğretimdeki brüt okullaşma oranları \%90'lara yaklaşırken net okullaşma oranı ise \%46'dır (Gür, Çelik ve Yurdakul, 2019). Açıkçası bu oranlar Tekeli'nin yükseköğretimdeki okullaşma oranı hedefinden düşük, yüz yüze öğretim programlarındaki öğrenci sayısı ise tanımlanan hedefe yakındır. Açıöğretim sistemi ise dünyada eşi benzeri olmayan devasa bir sisteme dönüşmüştür. Açıköğretim sistemi bu haliyle sürdürülebilir olmayan bir yapıdadır ve yükseköğretim sistemi içindeki payı mutlaka küçültülmelidir (Çetinsaya, 2014; Gür, Çelik \& Yurdakul, 2018; 2019; Tekeli, 2010a; YÖK, 2007).

Türkiye yükseköğretim sistemi gerçekten de aşırı büyümüş, her yere üniversiteler açllmış dünyada eşi benzeri olmayan bir sistem midir? Türkiye'de 207 üniversite ve vakıf meslek yüksekokulu vardır. Bunların beşi kurulmuş 
olmasına rağmen halen herhangi bir faaliyeti yoktur. Açıkçası ABD ve Avrupa'da yükseköğretim sistemleri 1960'larda hızlı bir büyüme yaşamıştır. 2000'li yıllarda Türkiye ile Çin yükseköğretim sistemini yoğun bir şekilde büyütmeye çalışan ülkelerdir. Türkiye'deki yükseköğretim kurum sayısını dünya ile kıyaslamak Türkiye yükseköğretim sisteminin büyüklüğü hakkında bir fikir verecektir. Bunun için bir milyon kişi başına düşen üniversite sayısı üzerinden bir hesaplama yapılmıştır. Buna göre hesaplamada Türkiye'de bir milyon kişiye 2,1 yükseköğretim kurumu düşerken $\mathrm{ABD}$, Rusya, Danimarka, Malezya, Polonya, İsviçre ve Norveç'te ise bir milyon kişiye 10 ve üzeri yükseköğretim kurumu düşmektedir. Bir milyon kişi başına düşen yükseköğretim kurumu sayısı üzerinden yapılan hesaplamalara göre Türkiye'ye benzer ya da daha düşük nüfusa sahip Polonya ve Malezya' da 400'ün üzerinde, Kanada ve Güney Kore'de 300'ün üzerinde; İspanya, İtalya ve Birleşik Krallık da ise 200'ün üzerinde yükseköğretim kurumu vardır (Gür vd., 2017). Buna ilaveten, Türkiye'de yükseköğretim sistemine giren ve sistemden mezun olan öğrenci sayısı son yıllarda artmasına rağmen OECD ülkeleri ile kıyasladığında Türkiye'deki yükseköğretim mezun oranları hayli düşüktür. 2017 yılı verilerine göre OECD ülkelerinde 25-64 yaş arası yükseköğretim mezuniyet oranı \%38 iken bu oran Türkiye' de \%20; 25-34 yaş arasında ise OECD ülkeleri oranı \%44 iken Türkiye'nin oranı \%32'dir (OECD, 2018). Açıkçası yükseköğretime yönelik talebin bu kadar büyük olduğu ve dünya ile kiyaslandığında yükseköğretim kurum sayısının ve yükseköğretim mezun oranlarının düşük olduğu dikkate alındığında, yükseköğretim sisteminin büyümesi gerekmektedir.

Türkiye'de yeni açlan üniversitelerin ürettiği değere yönelik geniş kapsamlı analizler yapmadan yeni açılan üniversitelerin kalitesinin düşük olduğunu iddia etmek doğru bir yaklaşım değildir. Somut bir veri olarak bazı bölümlerin üniversiteden mezun olduktan sonra girdikleri KPSS puanına bakıldığında, yeni üniversitelerin katkısına dair bir şey söylenebilir. Öğretmenlik alanındaki birçok programa ilaveten, tıp, hukuk, iktisat ve sosyoloji gibi bölümlere girişte üniversiteler arasında taban puanları önemli ölçüde farklılaşırken, mezuniyet sonrası KPSS puanlarında oldukça düşük puanla öğrenci alan ikinci ve üçüncü dalga üniversitelerin birinci dalgadaki üniversiteler kadar ortalama puana sahip olduğu görülmektedir. Bu ise yeni açlan üniversitelerden mezun olanların kamuda istihdam konusunda birinci dalga üniversiteler kadar firsata sahip olduğunu göstermektedir. Dolayısıyla yeni açllan üniversitelerin öğrencilerine önemli katkıda bulunduğu söylenebilir (Gür, 
Çelik ve Yurdakul, 2018). Tekeli'nin ifadesi ile toplumun dezavantajlı kesimleri kısmen dahi olsa yükseköğretime dahil olarak dikey hareketlilik fırsatına sahip olmaktadır.

Yükseköğretimde kalite ile ilgili en önemli gösterge doktoralı öğretim üyesi sayısı ve öğretim üyesi başına düşen öğrenci sayılarıdır. Türkiye'de toplam 166 bin öğretim elemanı var ve bunların 81 bini öğretim üyesi statüsündedir. UNESCO verileri kullanılarak yapılan hesaplamaya göre Türkiye'de öğretim elemanı başına 43, Birleşik Krallık'ta 16, ABD'de 12, Kanada'da 9, Almanya'da 8 ve Japonya'da 7 öğrenci düşmektedir. Buradaki asıl sorun üniversitelere göre öğretim elemanı ve üyesi başına düşen öğrenci sayısının aşırı derecede farklılaşmasıdır. Bir yanda öğretim üyesi başına 100 'den fazla öğrenci düşen üniversiteler varken diğer tarafta $20^{\prime}$ den az öğrenci düşen üniversiteler bulunmaktadır (Gür, Çelik ve Yurdakul, 2019). Öğretim üyesi ihtiyacının acilen karşılanması için doktoralı insan kaynağına ihtiyaç vardır. Buna ilaveten, katma değeri yüksek ürün üretecek olan yüksek teknoloji alanında çalışan yüksek nitelikli işgücü anlamına gelmektedir. Ancak Türkiye, geçmişe göre önlisans ve lisansta erişim ve yükseköğretimden mezuniyet konusunda bir ilerleme kaydetmesine rağmen kalite ile ilişkili olan doktora mezunu sayısında maalesef bir ilerleme sağlamamıştır. Türkiye en büyük on ekonomi ile kıyasladığında lisans mezuniyetinde Türkiye kendisine benzer ya da daha küçük nüfusa sahip ülkelerden çok daha fazla lisans mezunu verirken doktora düzeyinde ise on büyük ekonomideki tüm ülkelerden daha düşük sayıda mezun vermektedir. 2016 yılına ABD 70 bin, Çin 55 bin ve Almanya 29 bin doktora mezunu verirken Türkiye'nin 2018 yılında doktora mezun sayısı 7 bindir. Doktora mezunu açısından Türkiye'nin on büyük ekonomi ile rekabet etmesi mümkün görünmemektedir. Buna ilaveten 1416 sayılı Kanun ile yurt dışında lisansüstü eğitim için gidenlerden dönen ve göreve başlayan sayısı çok sinırlıdır. 2014-2018 yılları arasındaki 5 yıllık süreçte toplam 827 kişi doktorasını tamamlayıp göreve başlamıştır (Gür, Çelik ve Yurdakul, 2019). Büyüyen yükseköğretim sistemi ve Araştırma ve Geliştirme (AR-GE) çalışmalarının nitelikli yapılması için doktoralı öğretim üyesi ve işgücüne ihtiyaç kaçınılmazdır (Çetinsaya, 2014; Erdoğmus, 2019; Gür, Çelik, Kurt, \& Yurdakul, 2017; Gür, Çelik, \& Yurdakul, 2018; Özer, 2011; YÖK, 2007). Ancak YÖK'ün sıklıkla kaliteden bahsedip, doktoralı öğretim üyesi yetiştirme konusunda aktif adımlar atmaması, yükseköğretim sistemi için sorunlu bir durumdur. Dahası YÖK, Saraç döneminde 2015 yılında öğretim üyesi yetiştirme konusunda önemli bir işlev gören Öğretim Üyesi Yetiştirme Programı (ÖYP)'nı kaldırmıştır. YÖK, ÖYP yerine 100/2000 YÖK 
Doktora Bursu programını başlatmıştır. Bu program kapsamında öncelikli olarak belirlenen alanlardaki öğrencilere burs verilmektedir. Bu programın ne kadar etkin çalıştığına dair kamuoyu ile paylaşılan veri bulunmamaktadır.

Doktora programları ile ilgili YÖK'ün yaptığı düzenlemelerden biri de doktora programı açma şartıdır. Doktora programı açmak için iki profesör ya da bir profesör iki doçent altı doktoralı öğretim üyesine gerek vardır. Bu öğretim üyelerinden en fazla ikisi "yabancı uyruklu" olabilmektedir (YÖK, t.y.). YÖK'ün kararına göre bir profesörlüğün varlığında iki doçent bir profesör ederken, profesörün olmadığı durumda sayısız doçent ve doktor öğretim üyesi bir profesör etmemektedir (Gür, 2014). Buna ilaveten, yine bir bölümde dünyanın en iyi üniversitelerinden doktoralı Türkiye vatandaşı olmayan onlarca öğretim üyesi bir araya geldiği takdirde bile Türkiye'de doktora programı açamamaktadır. Bu kararın kaliteyi artırmaktan ziyade azaltıı bir etkisi olması muhtemeldir. İlaveten YÖK açık bir şekilde unvanlar arasında bir hiyerarşi kurmakta, kaliteye, araştırmaya vb. değil, unvana/kıdeme indirgemekte ve unvanlara/kıdeme kutsiyet atfetmektedir.

Kalite ile ilgili en önemli göstergelerden biri uluslararası öğretim elemanı sayısıdır. Türkiye'de uluslararası öğretim elemanı sayısı 3,2 bindir. Bunların 1,2 bini öğretim üyesi statünde çalışmaktadır. Uluslararası öğretim elemanlarının çoğu dil okulları ya da farklı dil programlarında çalışmaktadır (Gür, Çelik ve Yurdakul, 2019). Buradaki en temel problem Türkiye'nin uluslararası öğretim elemanı için koyduğu \%2 kotasıdır. Üniversitenin tarihsel olarak en temel özelliklerinden birisi uluslararasılaşmadır (Tekeli, 2010b). Türkiye ise kota uygulaması ile doğrudan bu uluslararasılığı kısıtlamanın peşindedir. Avrupa'daki ülkeler arasında Türkiye uluslararası öğretim eleman oranı en az olan ülkedir. Buna ilaveten, saygın yükseköğretim kurumlarındaki uluslararası öğretim elemanı oranı \%40'lardan daha yüksektir (ETER, 2019).

Kalite ile ilgili bir diğer husus ise son 20 yılda ilk kez Türkiye, kalitenin en önemli göstergelerinden biri olan akademik yayıncılıkta sıralamada gerilemiştir. Türkiye 2017 yılında, Türkiye adresli yayınlarda hem Web of Science hem de Scopus'ta bir gerileme yaşamıştır. Türkiye adresli yayınların Web of Science'daki oranı bir önceki seneye göre $\% 1,58^{\prime}$ den $\% 1,44^{\prime}$ e düşmüştür. Scopus'ta ise 43 binden 39 bine inmiş, Türkiye bu sıralamada 17. sıradan 19. s1raya gerilemiştir (Gür, Çelik ve Yurdakul 2019).

\section{Sonuç}


İlhan Tekeli, 50 yıllık akademideki tecrübeleri ve yükseköğretim üzerine çalışmaları ile Türkiye yükseköğretim sisteminin tarihsel gelişimi, yükseköğretim sisteminin karşılaştığı sorunları ve güçlükleri, yükseköğretim sistemini iyileştirmek için yapılması gerekenler üzerine tartışmalar yürütmüştür. Yükseköğretim sisteminin tarihsel gelişimi içinde üniversite özerkliğinin YÖK ile birlikte ortadan kalktığını, güçlü ve merkeziyetçi bir YÖK'ün üniversite özerkliğini sınırladığını, üniversitelerde güçlü rektörlerin akademik özgürlük açısından ve üniversitelerin demokratikleşmesi açısından sorunlara neden olduğunu ifade etmiştir. Tekeli, yükseköğretim tarihini ve genel sorunlarını kurumsal özerklik bağlamında tartışmıştır (Gür, 2011). Buna ilaveten, üniversitelerin demokratikleşmesindeki sorunu sadece bir YÖK sorunu olarak değil, güçlü rektör sorunu olarak tanımlaması, yükseköğretim sisteminin büyümesine yönelik pozitif yaklaşımı, yükseköğretim sistemi büyürken kalitenin mutlaka dikkate alınması gerektiği vurguları ile Türkiye' deki oldukça yaygin olan yaklaşımlardan farklılaşmaktadır.

Tekeli'nin 50 yıldır yükseköğretim sistemi ile ilgili olarak dile getirdiği birçok problemin çözülmediği ve halen karşımızda önemli sorunlar olarak durduğu görülmektedir. Yükseköğretim reformu, toplumun ve üniversitelerin belirli bir kesimi tarafından halen dile getirilmesine rağmen maalesef siyasal gündemdeki önemini kaybetmiştir. YÖK varlığını ve neden olduğu tüm sorunlarını daha da büyümüş bir şekilde "yeni YÖK" olarak devam ettirmektedir. Yükseköğretimde dünyada ve Türkiye'de yaşanan değişimler ile Türkiye'deki yönetim sisteminin değişmesi sonrasında yükseköğretimin yeniden tasarlanmasını gerekli kılmaktadır.

Türkiye'de önce Cumhurbaşkanının halk tarafından seçilmesi ardından Cumhurbaşkanlığı sistemine geçiş yükseköğretim sisteminin yönetiminde bir değişimi gerekli kılmaktadır. 12 Eylül sonrasında siyaseten hesap verebilirliği sınırlı bir Cumhurbaşkanı tarafından yükseköğretim sisteminin üst yönetimi dizayn edilmekteydi. Gelinen noktada, halk tarafından seçilen partili bir Cumhurbaşkanın teorik olarak hesap verebilirliği yüksektir. Seçilmiş bir iktidar tarafından üniversite üst yönetiminin belirlenmesi uygulaması başarılı yükseköğretim sistemlerinde de görülmektedir. Ancak Türkiye'de aşırı siyasal bir figür olarak Cumhurbaşkanının YÖK başkanı ve üyeleri ile rektörleri ataması yükseköğretim sisteminde aşırı siyasallaşmaya neden olacağı yönelik bir kaygı oluşturmaktadır. Açıkçası, Yükseköğretim sistemindeki sorunların kaynağı, yükseköğretim üst yönetiminin Cumhurbaşkanı tarafından atanması değil, aşırı güçlü bir YÖK ve başkanının olması ve yine aşırı 
yetkili ve güçlü bir rektörün varlığı ile akademik özgürlüklerin sınırlı olmasıdır. Bu sistem içinde öğretim üyelerinin taleplerini özgürce dile getirmesi güçtür. Buna ilaveten, yükseköğretim kanunun temel amaç olarak araştırma, bilim ve akademik özgürlük gibi hususları merkezine almaması, yükseköğretimdeki sorunları derinleştirmektedir. Yükseköğretim üst yönetiminin tamamen üniversite içi ya da kamu bürokrasisi tarafından oluşması ise toplum ile olan bağı zayıflatmaktadır.

Türkiye yükseköğretim sistemi şimdiye kadar deneyimlediği olumsuzlukları aşacak, kaliteli, toplumsal taleplere duyarlı, akademik özgürlüğün garanti altına alındığı, hesap verebilirliğin ve şeffaflığın tam olarak sağlandığ kapsamlı bir yükseköğretim öğretim reformuna ihtiyaç vardır. Öncelikli olarak YÖK başkanı ve rektör merkezli, toplumsal taleplere duyarsız bir yükseköğretim üst yönetim sistemi yerine, üyelerinin çoğunluğunun ya da tamamının üniversite dışı aktörlerden oluştuğu bir üst yönetim sistemi tasarlanmalıdır. Diğer bir husus bu kurul icracı bir kurul değil, yükseköğretime yönelik temel politikaların belirlendiği bir kurul olmalıdır. İlaveten, bu kurulun başkan merkezli bir kurul yerine, tam bir kurul hüviyetine sahip olması ve tüm üyelerinin eşit yetki ve sorumluluğa sahip olması gerekir. Rektör seçimlerinin neden olduğu sorunlar ve dünyadaki eğilimler dikkate alınarak, rektörün icracı olduğu, senatonun yetkilerinin artırıldığı, senato üyelerinin rektör tarafından belirlenmediği, üniversiteye ilişkin kararların tam bir kurul işleyişi içinde yürüdüğü bir yapı ihdas edilmelidir. Rektörün yetkileri sınırlanırken, üniversite özerkliği ve akademik özgürlüklerin genişletilmesine özen gösterilmelidir. Tekeli (2012), yükseköğretim sisteminin yönetimine ilişkin şu uyarı yapmaktadır. Gerçek anlamda hesap verebilirliğin olmadığı bir sistemde özerklik sistemi diktatörlüğe götürebilir. Bundan dolayı bir yükseköğretim sistemi tasarlanırken özerklik/hesap verebilirlik dengesinin çok iyi kurulması gerekmektedir. Yöneticilere yeterli yetkinin sağlanması ama bu yetkininde keyfi kullanılması engellenmeli, aksi taktirde bu yetkinin öğretim üyeleri üzerinde kolayca bir baskı aracına dönüşebilir. Bundan dolayı kurumsal özerklik ile akademisyenin akademik özgürlüğü birlikte talep edilmelidir.

Açıkçası, ideolojik dayatma ve endokrinasyon yerine bilimi, araştırmayı ve akademik özgürlükleri üniversitenin temel amacı olarak tanımlayan, şeffaf ve hesap verilebilir bir sistemin ihdası ve üst yöneticilerin yetkilerinin azaltıldığı ve dengelendiği bir yükseköğretim sistemi mevcut birçok sorunun çözülmesine katkısı olacaktır. Ancak, sadece yasal düzenlemelerin yükseköğretim sisteminin sorunun çözmesi beklenmemelidir. Üniversiteyi bilim ve 
araştırmanın merkezi olarak gören ve toplumsal sorunlara duyarlı bir yükseköğretim kültürünün de oluşması gerekmektedir.

Son olarak, Türkiye'de yükseköğretime yönelik talep her geçen gün büyük oranda artmakta, ortaöğretimden mezun sayısı ve oranlarının yükselmekte, yükseköğretime yönelik talebin büyüklügüne rağmen kontenjanlar aynı oranda artmamaktadır. Hatta ortaöğretimden yeni mezun her 10 kişiden 7'si bir programa yerleşmemiştir. Buna ilaveten, Türkiye'de yükseköğretimdeki net okullaşma oranı ve mezuniyet oranı dünya ile kıyaslandığında halen oldukça düşüktür. Yükseköğretim sistemi gelişmiş ülkelerdeki üniversite sayısı ve nüfusa oranına bakıldığında Türkiye'deki üniversite sayısının daha düşük olduğu görülmektedir. Tüm bu gerekçeler Türkiye'deki yükseköğretim sisteminin büyümeye devam etmesini zorunlu kılmaktadır. Yükseköğretim sistemi büyümeye devam ederken kaliteyi koruyabilmesi için Tekeli'nin de yıllar önce ifade ettiği gibi çok daha yüksek sayıda doktora mezunu verilmelidir. Öğretim üyesi başına düşen öğrenci sayısı azaltılmalı, öğretim elemanı başına düşen öğrenci sayısı açısından üniversiteler arasında daha eşitlikçi bir yapı kurulmalıdır. Doktoralı öğretim elemanı yetiştirmek için, araştırma görevlisi kadrolarının artırılması, farklı destek programları ile yurt içi ve yurt dışı burs programları etkinleştirilmelidir. Buna ilaveten, kaliteli uluslararası öğretim elemanlarının Türkiye'deki oranı ve sayısının artırmak için $\% 2$ kotasının bir an önce kaldırılması gerekmektedir. 


\section{Extended Abstract}

\section{Autonomy, Expansion, and Quality in Higher Education: An Analysis on İlhan Tekeli's Research on Higher Education \\ * \\ Zafer Çelik \\ ORCID: 0000-0003-0080-1142}

Although there is a trend on the number of research it is still very limited for the magnitude of the higher education system in Turkey. Being an academic, researcher and BHE member and, İlhan Tekeli's works on higher education are exceptional for us to to identify the history and problems of higher education in Turkey. This study examines how Tekeli analyses Turkey's higher education history, problems and autonomy in higher education, evolution of higher education, growth and quality issues.

According to Tekeli, the Humboldt-style is the ideal university system, where the rectors are elected by faculty members. The main feature of Humboldt-style, Universities are prioritizing to research and produce new knowledge over to the teaching of existing knowledge According to Tekeli, the Humboldt-style universities are independent in their curriculums and programs. Governments do not intervene in any aspect of university, except for fiscal budget audits (Tekeli, 1989; 2010b). By describing the Humboldtstyle universities as the ideal university model, Tekeli, claims that the transformation began to evolve after the World War II, and were destroyed the basic principles that universities inherent. Such as, the concept of professional management has been adopted since then instead of collegial university administration model, thus universities has become more market oriented.

Tekeli claims that board of trustees in the university administration is not a good practice. He asserts that if the members of the board of trustees are appointed by the government, education will not be neutral, the entire university administration will be established with political influences, the university will become more politicized, and there will be no connection between the board of trustees and the university. Obviously, a board governs universities, although they have different names, tasks, and functions in many developed countries (Fielden, 2008; Gür, 2016; Kurt, 2015). The boards govern 
the universities on behalf of the societies, governments, and founders (AGB, 2010; Martorana, 1963). In many countries, the board of trustees is seen as a means of strengthening the bond between the university, society, and establishing a more transparent and accountable administrations.

According to Tekeli, the presence of an extremely centralist and powerful BHE restricts the autonomy. Board of Higher Education (YÖK) is a presidentcentered board rather than a board with influence of the members of the general assembly. The president of the BHE has an indisputable position, therefore, president of the BHE effectively uses this power when he clashes with government or when he is at the full direction of government. The most important issue regarding university autonomy is the excessive power and authority of the BHE over universities. For Tekeli, another important issue with autonomy is the extremely strong and exceptional powers of rectors, that makes hardly impossible to mention the freedom of faculty members and a participatory administration. Tekeli argues that the senate and faculty committees do not have enough power comparing to rector or deans therefore increasing the autonomy will lead to a new crisis and that "can create new feudal lords." (Tekeli, 2011, p. 181). For Tekeli, the election of the rectors by the faculty members is not the only indicator of autonomy and democratic governance. Because election process have been affected by faculty distribution, being part of a political group or physical pressure. Also the current rector may play an active role in the election process for the sake of candidate rector.

Tekeli $(1972,1994,2011)$ has discussed the issue of expansion in higher education since the 1970s. He discussed the issue of expansion in the contexts of fulfilling the need for qualified human resources, demographic change, human rights and equality of educational opportunity. He stated that expansion in higher education would have positive outcome for youth, society, and in general for Turkey. However, in terms of expansion, Tekeli also noted that quality should be indispensable component of the higher education and the number of $\mathrm{PhD}$ graduates should be increased urgently.

As a result, Tekeli stated that in the historical development of the higher education system the autonomy of universities has disappeared simultaneously with the emergence of BHE. The over-centralized BHE limits the autonomy of universities, and also rectors with excessive authority eradicate the academic freedom and democratization of universities. Having very strong and over-empowered rectors weakens the functions of senates and boards is the major problem for the university in Turkey. Tekeli emphasizes the need 
for a higher education reform that will reveal a more democratic, accountable and transparent higher education system and maintain university autonomy. Finally, Tekeli states that the higher education system should expand, and quality must be taken into account when this expansion takes place.

\section{Kaynakça/References}

Association of Governing Boards of Universities and Colleges. (2010). Policies, practices, and composition of governing boards of public colleges, universities, and systems. Association of Governing Boards of Universities and Colleges. TIAA, CREFF Insititute.

"YÖK Başkanı'ndan 'üniversite kontenjanı' açılaması". (2020, 7 Ocak). Memurlar.net. https://www.memurlar.net/haber/878040/yok-baskani-ndan-universite-kontenjani-aciklamasi.html

AAUP. (1915). 1915 Declaration of Principles on Academic Freedom and Academic Tenure. Retrieved from www.aaup.com. 15 Ocak 2014 tarihinde http://www.aaup.org/file/1915-Declaration-of-Principles-o-nAcademic-Freedomand-Academic-Tenure.pdf adresinden erişilmiştir.

Altbach, P. G. (2001). Academic freedom: International realities and challenges. Higher Education, 41(1/2), 205-219.

Bleikle, I. ve Kogan, M. (2007). Organization and governance of universities. Higher Education Policy, 20, 477-493. doi:10.1057/ palgrave.hep.8300167

Bilsel, C. (1943). İstanbul Üniversitesi tarihi. İstanbul Üniversitesi Yayınları.

Çelik, Z., Bozgeyikli, H. ve Yurdakul, S. (2019). Eğitime bakış, 2019: İzleme ve değerlendirme raporu. Ankara: Eğitim-Bir-Sen Stratejik Araştırmalar Merkezi.

Çelik, Z. ve Gür, (2012). Akademik özgürlüğe kör bir bakış. Ĕğitime Bakış Eğitim-Öğretim ve Bilim Araştırma Dergisi, 8, 28-31.

Çelik, Z. ve Gür, B. S. (2014). Yükseköğretim sistemlerinin yönetimi ve üniversite özerkliği: Küresel eğilimler ve Türkiye örneği. Yükseköğretim ve Bilim Dergisi, 4(1), 18-27.

Çetinsaya, G. (2014). Büyüme, kalite, uluslararasılaşma: Türkiye yükseköğretimi için bir yol haritası. Eskişehir: Yükseköğretim Kurulu.

De Boer, H. ve File, J. (2009). Higher education governance reforms across Europe. Brussels: ESMU.

Dogramacı, İ. (2007). Tǚkiye'de ve Dünyada yuksekö̆retim yönetimi. Ankara: Meteksan Yayınları.

Downs, D.A. (2009). Academic freedom: What it is, what it isn't, and how the tell the difference. Raleigh, NC: John W. Pope Center for Higher Education Policy. http://www.popecenter.org/ac- robat/AcademicFreedom.pdf

Erdoğmuş, N. (2019). Geleceğin Türkiye'sinde yükseköğretim. İstanbul: ILKE İlim Kültür Eğitim Derneği.

Ergüder, Ü. (2015). Yükseköğretimin firtınalı sularında. İstanbul: Doğan Kitap. 
Ergüder, Ü., Şahin, M., Terzioğlu, T. ve Vardar, Ö. (2009). Neden bir yükseköğretim vizyonu. İstanbul: İstanbul Politikalar Merkezi

Estermann, T., Nokkola, T., Steinel, M. (2011). University autonomy in Europe II: The scorecard. Brussels: European University Association.

ETER. (2019). Internationalization of higher education staff in European higher education. https://www.eter-project.com/uploads/analytical-reports/ETER_AnalyticalReport_01_final.pdf

Fielden, J. (2008). Global trends in university governance. Washington, D.C.: The World Bank.

Günay, D. (2019a). Türkiye'nin üniversite sorunu trajik bir yolculuk. İstanbul: Büyüyenay. Günay, D. (2019b). Üniversite felsefesi. İstanbul: Büyüyenay.

Gür, B.S. (2011). “Türkiye' de yükseköğretimin ve Yükseköğretim Kurulu'nun tarihi” üzerine. Yükseköğretim ve Bilim Dergisi, 1(1), 47-53.

Gür, B.S. (2014, 18 Aralı). YÖK: bir profesör kaç doçent eder?. Star. https://www.star.com.tr/yazar/yok-bir-profesor-kac-docent-eder-yazi-981912/

Gür, B. S. (2016). Egemen üniversite: Amerika'da yükseköğretim sistemi ve Türkiye için reform önerileri. İstanbul: EDAM

Gür, B. S. ve Çelik, Z. (2011). YÖK'ün 30 yılı. Ankara: Siyaset, Ekonomi ve Toplum Araştırmaları Vakfı.

Gür, B. S., Çelik, Z., Kurt, T., Yurdakul, S. (2017). Yükseköğretime bakış, 2017: İleme ve değerlendirme raporu. Ankara: Eğitim-Bir-Sen Stratejik Araştırmalar Merkezi.

Gür, B. S., Çelik, Z., Yurdakul, S. (2018). Yükseköğretime bakış, 2018: İzleme ve değerlendirme raporu. Ankara: Eğitim-Bir-Sen Stratejik Araştırmalar Merkezi.

Gür, B. S., Çelik, Z., Yurdakul, S. (2019). Yükseköğretime bakış, 2019: İzleme ve değerlendirme raporu. Ankara: Eğitim-Bir-Sen Stratejik Araştırmalar Merkezi.

Gürüz, K. (2008). Yirmi birinci yüzyılın başında Türk milli egĭtim sistemi. Istanbul: Türkiye İş Bankası Yayınları.

Gürüz, K. (2015). Aklımdan başka silahım yok ki! İstanbul: Ka Kitap.

Kurt, T. (2015). Yükseköğretimin yönetiminde mütevelli heyetleri. Ankara: Ankara: Siyaset, Ekonomi ve Toplum Araştırmaları Vakfı.

Kurt, T., Gür, B.S., Çelik, Z. (2017). Necessity for reforming Turkish higher education system amd possibility of governance of state universities by the board of trustees. Education and Science, 42(189), 49-71.

Küçükcan, T. ve Gür, B. S. (2009). Türkiye'de yükseköğretimde: Karşılaştırmalı bir analiz. Ankara: Ankara: Siyaset, Ekonomi ve Toplum Araştırmaları Vakfı.

Martorana, S. V. (1963). College boards of trustees. Washington, DC: The Center for Applied Research in Education.

OECD. (2003). Changing patterns of governance in higher education. Education policy analysis. Paris: OECD.

OECD. (2018). Education at a glance 2018. Paris: OECD.

O'Neil, R. M. (1999). Academic freedom: Past, present, and future. P. G. Altbach, R. O. Berdahl ve P. J. Gumport (Ed.), American higher education in the twenty-frst century: 
Social, political, and economic challenges, içinde (s. 89-108). Baltimore: The Johns Hopkins University Press.

Özer, M. (2011). Türkiye' de yüksekögretimde büyüme ve ögretim üyesi arzı. Yüksekögretim ve Bilim Dergisi, 1(1), 23-26.

Saraç: YÖK yasası yeniden ele alınacak. (2014, 29 Kasım). Memurlar.net. https://www.memurlar.net/haber/491654/

Seggie, F.N. ve Gökbel, V. (2014). Geçmişten günümüze Türkiye'de akademik özgürlük. Ankara: Siyaset, Ekonomi ve Toplum Araştırmaları Vakfı.

Szyliowicz, J. S. (1994). Education and political development. M. Heper \& A. Evin (Ed.), Politics in the third Turkish republic, içinde (s.147-159). Boulder, CO: Westview.

Tekeli, İ. (1972). Büyükkent dışı üniversitelerin kuruluş yeri sorunları üzerine. Mimarlık, 10 (12), 36-40.

Tekeli, İ. (1989). Dünyada üniversitenin yaşamakta olduğu dönüşüm üzerine düşünceler. Planlama, 89(2-3-4), 3-11.

Tekeli, İ. (1994). Üniversite üzerinde bir kez daha konuşurken. Birikim, 67, 36-40.

Tekeli, İ. (2010a). Tarihsel bağlam içinde YÖK ve Yükseköğretimin tarihi. İstanbul: Tarih Vakfi Yurt Yayınları.

Tekeli, İ. (2010b). Ĕgitim üzerine düşünmek (3. baskı). Ankara: Türkiye Bilimler Akademisi.

Tekeli, İ. (2011). Türkiye için eğitim yazıları. İstanbul: Tarih Vakfı Yurt Yayınları.

Tekeli, İ. (2012). Yükseköğretimde yeniden düzenleme arayışlarının nasıl temellendirileceği üzerine. Yükseköğretim ve Bilim Dergisi, 2, 6-10.

Tekeli, İ. (t.y.). Türkiye'nin Yükseköğretim Stratejisi (2007)-Eğitim Vizyonu.

Tekeli, İ. (2019). Modern Türkiye' de bilim ve üniversite (1923-2019). A. Şimşek (Ed.) Modern Türkiye tarihi, içinde (s.283-311). Ankara: PEGEM Akademi.

Tunçay, M. (1984). YÖK. Cumhuriyet dönemi Türkiye ansiklopedisi, cilt III, içinde (s. 680688). Istanbul: Iletișim.

World Bank. (2007). Turkey: Higher education policy study, Volume 1. Strategic directions for higher education in Turkey (Rapor No. 39674). Washington, DC: The World Bank YÖK. (2007). Türkiye'nin yüksekögřetim stratejisi. Ankara: Yüksekögretim Kurulu.

YÖK. (t.y.). Doktoralsanatta yeterlilik program açmak için başvuru formatı. https:/www.yok.gov.tr/kurumsal/idari-birimler/egitim-ogretim-dairesi/doktoraprogrami-acma-olcutleri 